\title{
PENINGKATAN KETERAMPILAN MEMBACA PEMAHAMAN MELALUI METODE HYPERSCAN PADA SISWA SMA MUHAMMADIYAH 2 PALEMBANG
}

\author{
Mulyati \\ Dosen Universitas Muhammadiyah Palembang \\ Jalan Jend. A. Yani 13 Ulu Palembang \\ Sur-el: mulyatitaufiq@co.id
}

Article info

Article history:

Received: 12-04-21

Revised : 20-04-21

Accepted: 10-06-21

Keywords:

Hyperscan, Reading

Comprehension

narrative discourse, CAR

Kata Kunci:

Hyperscan,

Membaca

Pemahaman, Wacana

Narasi, PTK

\section{A B S T R A C T}

The hyper-scan method is one way that instructors employ to help students in class XI improve their reading comprehension. Indeed, many students struggle with reading comprehension. This is a Classroom Action Research (CAR) research comprising two cycles of 4 stages: planning, action, observation, and reflection. $M=\frac{\sum N}{\Sigma X}$ was used to analyze the test data. The result shows the average pre-cycle score was 63.83 , the first cycle score was 73.77, and the second cycle score was 84.33. According to the percentage of students who qualify, there has traditionally been an increase. The percentage of completion in pre-cycle tests ranged from $10 \%$ to 46.6 percent in the first cycle and up to $90 \%$ in the second cycle. As a result, it can be concluded that the hyper-scan method can assist in reading comprehension skills development.

Metode hyperscan salah satu metode yang digunakan guru dalam pembelajaran membaca pemahaman yang harus dikuasai siswa SMA kelas XI. Faktanya, banyak siswa yang belum maтpu dalam membaca pemahaman.Penelitian ini merupakan Penelitian Tindakan Kelas (PTK) dengan dua siklus. Terdiri dari 4 tahap: perencanaan, tindakan, pengamatan dan refleksi. Data tes dianalisis menggunakan rumus $M=\frac{\sum N}{\Sigma X}$. Dari hasil penelitian, nilai rata-rata siswa pada prasiklus adalah 63,83, siklus I 73,77, siklus II 84,33. Dilihat dari persentase keberhasilan siswa, secara klasikal terjadi peningkatan. Tes prasiklus persentase ketuntasan $10 \%$ menjadi $46,6 \%$ pada siklus I, menjadi $90 \%$ pada siklus II. Dengan demikian, disimpulkan bahwa metode hyperscan dapat meningkatkan keterampilan membaca pemahaman wacana narasi siswa.

Direktorat Riset dan Pengabdian Masyarakat Universitas Bina Darma. 


\section{PENDAHULUAN}

Pembelajaran Bahasa Indonesia pada hakikatnya adalah suatu pembelajaran yang bertujuan untuk meningkatkan kemampuan keterampilan berbahasa yang meliputi empat aspek, yaitu kemampuan menyimak, berbicara, membaca dan menulis. Keempat aspek tersebut sangat penting dalam proses pengajaran di sekolah. Taringan (2008:7) menyatakan bahwa membaca adalah suatu proses yang dilakukan serta dipergunakan oleh pembaca untuk memperoleh pesan yang hendak disampaikan oleh penulis melalui media kata-kata atau bahasa tulis. Oleh sebab itu, tugas pengajar dalam kegiatan pembelajaran adalah memilih dan menentukan metode yang akan digunakan. Pada pembelajaran Bahasa Indonesia, khususnya membaca diperlukan pemilihan metode yang tepat agar tujuan pembelajaran dapat tercapai dengan maksimal. Sebuah metode akan dikatakan baik bila sesuai dengan tujuan yang hendak dicapai dan dapat dilaksanakansesuai dengan kemampuan pengajar.

Pada keterampilan berbahasa, membaca merupakan suatu keterampilan yang sangat berperan penting bagi pengembangan pengetahuan dan sebagai alat komunikasi bagi kehidupan manusia. Membaca dikatakan penting bagi pengembangan pengetahuan karena presentase transfer ilmu pengetahuan terbanyak dilakukan melalui membaca (Sunendar dan Iskandarwassid, 2009:245). Dengan begitu, kemampuan membaca sangat berpengaruh pada keberhasilan siswa dalam proses belajar di sekolah. Tujuan utama dalam membaca ialah untuk mencari dan memperoleh informasi, mencakup isi dan memahami makna bacaan.Jenis membaca yang perlu dikuasai dalam dunia ilmu pengetahuan dan kesusastraan cukup banyak. Membaca pemahaman tergolong jenis membaca intensif. Membaca intensif salah satu kunci pemerolehan ilmu pengetahuan karena penekanannya adalah persoalan pemahaman yang mendalam, pemahaman ide-ide naskah dari ide pokok sampai ke ide-ide penjelas, hal-hal yang rinci.

Dalam Kurikulum 2013 (K-13), silabus Mata Pelajaran Bahasa Indonesia terdapat materi pembelajaran wacana narasi yang diajarkan pada siswa SMA Kelas XI Semester 1 dengan standar kompotensinya membaca memahami wacana tulis melalui kegiatan membaca intensif atau pemahaman dan membaca memindai. Kompotensi Dasar menemukan gagasan utama dalam teks yang dibaca.Indikator Pencapaian Kompotensi adalah siswa mampu mengungkapkan gagasan utama atau ide pokok dalam setiap paragraf 


\section{JURNAL ILMIAH \\ BINA EDUKASI \\ ISSN 1979-8598 E-ISSN: 2655-8378 \\ http://journal.binadarma.ac.id/index.php/jurnalbinaedukasi \\ Vol. 14, No. 1, Juni 2021, 46 - 58}

pada suatu teks bacaan dan mampu menata keistimewaan riwayat hidup tokoh, serta halhal yang dapat diteladani (Diknas, 2016:27).

Chaer (2007:267), mengatakan bahwa wacana adalah satuan bahasa yang terlengkap sehingga dalam hierarki gramatikal merupakan satuan tertinggi atau terbesar, wacana ini direalisasikan dalam bentuk karangan untuk (paragraf, novel, buku. kalimat atau kata). Adapun bentuk atau jenis-jenis wacana, yaitu (1) wacana narasi adalah cerita yang didasarkan pada urutan suatu kejadian, (2) wacana deskripsi adalah karangan yang menggambarkan suatu objek berdasarkan hasil pengamatan, perasaan, dan pengalaman penulisnya, (3) wacana eksposisi adalah karangan yang memaparkan atau menjelaskan secara terperinci, (4) wacana argumentasi adalah karangan yang berisi pendapat atau penilaian dengan alasan dan bukti-bukti yang logis.Berdasarkan pemaparan mengenai jenis-jenis wacana, peneliti menggunakan wacana narasi sebagai objek dari penelitian.

Selanjutnya Chaer (2007:272) menyatakan bahwa wacana narasi adalah rangkaian tuturan yang menceritakan atau menyajikan suatu hal atau kejadian melalui penonjolan tokoh pelaku dengan maksud memperoleh pengetahuan pendengar atau pembaca. Wacana narasi merupakan rangkaian tuturan yang menceritakan atau menyajikan suatu hal atau kejadian melalui penonjolan tokoh pelaku atau menceritakan suatu peristiwa atau kejadian yang bertujuan agar pembaca seolah-olah mengalami sendiri peristiwa tersebut yang diurutkan sesuai dengan urutan waktu dan tempat berlangsungnya.

Salah satu metode pembelajaran yang dapat memotivasi siswa dalam membaca pemahaman wacana narasi adalah metode pembelajaran Hyperscan. Metode hyperscan merupakan metode yang dapat meningkatkan kemampuan membaca pemahaman. Pada metode ini siswa di berikan teknik membaca dengan cepat serta mampu dengan cepat memahami isi bacaan. Menurut Deporter (2009:50) Hyperscan adalah metode membaca dengan menggunakan gerakan mata, teknik membalik halaman, serta jari telunjuk untuk membimbing kecepatan membaca. Teknik membalik halaman ini dikenal dengan sebutan metode menyapu halaman (brush matode). Teknik penggunaannya yaitu sambil membalik halaman dengan tangan kiri gunakan salah satu pola dan tangan kanan untuk membimbing mata.

Metode hyperscan tidak hanya dilihat untuk kecepatan membaca saja, namun juga dapat digunakan untuk kecepatan pemahaman terhadap bacaan. Untuk melihat tingkat kecepatan dan pemahaman terhadap bacaan berikan tes awal dan tes akhir untuk mengukur peningkatan tersebut. Metode hyperscan merupakan metode membaca dengan menggunakan kecepatan gerakan mata serta kecepatan tangan untuk membalik halaman 
dengan cepat. Teknik membalik halaman ini di kenal dengan sebutan metode menyapu halaman (brush metode). Teknik penggunaannya yaitu sambil membalik halaman dengan tangan kiri gunakan salah satu pola dengan tangan kanan untuk membimbing mata. Berdasarkan penejelasaan tersebut maka dapat dikemukakan cara membaca dengan menggunakan metode hyperscan.

Metode hyperscan mengajak siswa untuk meningkatkan kemampuan membaca serta memahami bacaan secara cepat. Pendapat ini di dukung oleh Nurhadi (2008:13) yang mengatakan mengapa kita dituntut untuk membaca cepat dan efektif. Pertama, yang perlu di ingat ialah bahwa membaca itu adalah sebuah proses yang kompleks dan faktor eksternal pembaca. Faktor internal dapat berupa intelegensi (IQ), minat, sikap, bakat, motivasi, tujuan membaca dan sebagainya. Faktor eksternal bisa dalam bentuk sarana membaca, teks bacaan (sederhana-berat, mudah-sulit) faktor lingkungan, sosial ekonomi, kebiasaan dan tradisi membaca. Bahwa pembaca yang baik adalah pembaca yang membaca dengan kecepatan tinggi serta memahami bacaan dengan tepat. Oleh sebab itu dibutuhkan konsentrasi penuh saat membaca. Metode hyperscan memberikan kesempatan kepada siswa untuk belajar secara efektif karena siswa dilibatkan dari awal proses pembelajaran sehingga siswa lebih cenderung mengingat apa yang mereka baca. Karena membaca merupakan kegiatan pokok dalam proses belajar. Pada metode hyperscan ini siswa diajak untuk membaca dengan konsentrasi penuh serta fokus terhadap bacaan agar kecepatan membaca dan tingkat pemahamannya akan semakin meningkat.

Deporter (2009:50) menjelaskan bahwa membaca dengan metode hyperscan dapat dilakukan melalui beberapa langkah. Pertama, memilih tempat yang tenang untuk membaca. Kedua, memeriksa fisiologi pembaca. Maksudnya, fisiologi pembaca adalah duduk di kursi dengan tegap, siapkan teks bacaan yang ingin dibaca, serta ambil waktu beberapa saat untuk menangkap pikiran dan memusatkan konsentrasi. Ketiga, melihat bahan bacaan secara sekilas selama satu menit. Keempat, berlatih membalik halaman. Kelima, putar kembali bahan bacaan dalam posisi yang benar. Keenam, melihat ke langitlangit dan memikirkan tentang suatu tempat yang damai. Ketujuh, tarik nafas dalam-dalam. Kedelapan, melihat ke arah bahan bacaan dan mulai membaca. Kesembilan, membalikkan halaman secara benar. Kesepuluh, menggunakan jari-jari dan mengikuti satu pola. Terakhir, mengajukan pertanyaan setelah selesai membaca pada diri sendiri.

Pada metode hyperscan teknik membalik halaman dilakukan dengan tangan kanan yang memegang buku terbuka diletakkan di tengah atas atau tepi kanan. Gunanya adalah untuk membalik halaman dengan kecepatan tinggi. Selanjutnya gunakan tangan kanan 
untuk membimbing kecepatan ketika membaca. Pola dibentuk adalah dengan cara tangan kiri yang memegang buku terbuka diletakkan di tegah atas atau tepi kanan, gunakan jari kanan untuk menyapu halaman kiri lalu halaman kanan secara vertikal dari atas ke bawah halaman kanan, railah dengan tangan kiri untuk membalik halaman dengan cepat

Penelitian dengan menggunakan model pembelajaran Hyperscan dengan materi wacana narasi ini pernah dilakukan oleh Nilfa Roy Hanny (2019) dengan judul “Keefektifan Metode Hyperscan Untuk Meningkatkan Membaca Pemahaman Wacana Narasi pada Siswa Kelas VII SMP Negeri 26 Palembang”. Hasil penelitian ini menunjukkan bahwa metode hiperscan efektif digunakan pada siswa kelas VII SMP Negeri 26 Palembang. Persamaan penelitian ini adalah sama sama menggunakan metode hyperscan, tetapi perbedaan yang dilakukan peneliti sebelumya yaitu terletak pada jenis penelitiannya. Jenis penelitian sebelumnya menggunakan eksperimen sedangkan penelitian ini menggunakan Penelitian Tindakan Kelas (PTK). Selanjutnya penelitian serupa pernah dilakukan oleh Yuni Oktaviani (2018) yang berjudul "Penggunaan Metode Hyperscan pada Pembelajaran Wacana Deskripsi dapat Meningkatkan Keterampilan Membaca Pemahaman Siswa Kelas XI SMA MUHAMMADIYAH 1 Palembang. Hasil penelitian yang dilakukan Yuni Oktaviani menunjukkan bahwa metode hyperscan dapat meningkatkan pembelajaran membaca pemahaman wacana deskripsi pada siswa kelas XI SMA Muhammadiyah 1 Palembang.

Persamaan penelitian ini terletak pada metode yang digunakan, yaitu menggunakan metode hyperscan, sedangkan perbedaannya adalah terletak pada objek dan jenis wacana yang digunakan. Pada penelitian sebelumnya menggunakan membaca pemahaman deskripsi, sedangkan penelitian ini menggunakan membaca pemahaman wacana narasi. Alasan peneliti memilih SMA Muhammadiyah 2 Palembang sebagai tempat penelitian ini berdasarkan pertimbangan karena sekolah ini merupakan salah satu sekolah swasta yang memiliki kualitas pendidikan dan pengajaran sangat baik, yaitu terbukti SMA Muhammadiyah 2 Palembang yang terakreditas A. Adapun kelas yang peneliti amati adalah kelas XI IPS 2 dengan jumlah 32 siswa. Peneliti melakukan Penelitian Tindakan Kelas dengan judul "Penggunaan Metode Hyperscan pada Pembelajaran Wacana Narasi dapat Meningkatkan Keterampilan Membaca Pemahaman Siswa Kelas XI SMA MUHAMMADIYAH 2 Palembang" karena metode Hyperscan ini belum pernah dipakai sebagai metode pembelajaran untuk mengukur keterampilan membaca pemahaman siswa terhadap wacana narasi. 


\section{METODOLOGI PENELITIAN}

Penelitan ini adalah Penelitian Tindakan Kelas, "Penelitian tindakan kelas adalah suatu pencermatan terhadap kegiatan belajar berupa sebuah tindakan, yang sengaja dimunculkan dan terjadi dalam sebuah kelas secara bersama" (Arikunto, dkk. 2011:2). Sedangkan menurut Aqib, dkk (2014:3), "Penelitian Tindakan Kelas (PTK) adalah suatu penelitian yang dilakukan oleh guru di kelasnya sendiri melalui refleksi diri dengan tujuan untuk memperbaiki kinerjanya sehingga hasil belajar siswa meningkat".Berdasarkan pengertian di atas, peneliti menyimpulkan Penelitian Tindakan Kelas adalah suatu pencermatan terhadap kegiatan belajar berupa sebuah tindakan yang dilakukan oleh guru di kelasnya sendiri melalui refleksi diri dengan tujuan meningkatkan hasil belajar siswa.

Lokasi penelitian ini dilakukan di SMA Muhammadiyah 2 Palembang, karena SMA Muhammadiyah 2 Palembang merupakan salah satu SMA yang terakreditasi A yang telah menerapkan Kurikulum 2013. Selain itu, sekolah ini juga telah dilengkapi oleh fasilitas yang mendukung proses belajar-mengajar dan materi membaca pemahaman wacana narasi terdapat dalam kurikulum 2013.Berdasarkan jumlah keseluruhan siswa kelaS XI SMA Muhammadiyah 2 Palembang tahun ajaran 2016/2017. Jumlah keseluruhan siswa kelas XI adalah 97 siswa yang terdiri dari 47 orang siswa laki-laki dan 50 orang siswa perempuan.

Instrumen penilaian dalam penelitian ini adalah tes, observasi, dan wawancara". Observasi adalah metode pengamatan yang merupakan suatu kegiatan pemusatan perhatian terhadap suatu objek dengan menggunakan seluruh alat indra" (Arikunto, 2011:199). Observasi digunakan untuk mengumpulakan data tentang partisipan siswa dalam proses belajar-mengajar dan emplementasi metode hyperscan. Observasi ditujukan kepada siswa kelas XI SMA Muhammadiyah 2 Palembang yang dilakukan bersamaan dengan pelaksanaan tindakan. Penulis langsung mengamati proses pembelajaran yang terjadi di dalam kelas. Untuk lebih jelasnya peneliti membuat lembar pengamatan.

Peneliti dalam penelitian ini lebih mengutamakan hasil tes keterampilan membaca wacana narasi. Tes objektif atau pilihan ganda hasil dari membaca wacana narasiyang diberikan berjumlah satu soal, yaitu membaca wacana narasi dengan menggunakan metode hyperscan. Tes keterampilan membaca wacana narasi dilakukan sebanyak tiga kali. Tes pertama, peneliti akan memberikan tes untuk membaca wacana narasi bertemakan bebas sebelum menggunakan metode hyperscan. Tes kedua, peneliti akan memberikan tes untuk 
membaca wacana narasi kepada siswa setelah memberi tau langkah-langkah metode hyerscan. Tes ketiga dilakukan dengan asumsi pada saat tes kedua kemampuan siswa belum optimal.

Teknik analisis data yang digunakan dalam penelitian ini adalah analisis kuantitatif dan analisis kualitatif. Peneliti secara kuantitatif dikatakan berhasil apabila siswa mencapai KKM yang telah ditetapkan. Secara kualitatif apabila siswa antusius, serius, aktif dalam proses pembelajaran yang dilakukan peneliti. Untuk mencari nilai rata-rata, peneliti menjumlahkan nilai yang diperolah siswa selanjutnya, dibagi dengan jumlah siswa kelas tersebut. Dengan demikian diperoleh nilai rata-rata didapat dengan menggunakan rumus berikut.

$$
M=\frac{\sum N}{\sum X}
$$

Sumber: Aqib (2011:40)

Keterangan :

$\mathrm{X}$ : Nilai rata-rata

$\sum \mathrm{X} \quad$ : Jumlah seluruh nilai siswa

$\sum \mathrm{N} \quad$ : Jumlah siswa

Untuk mendeskripsikan nilai siswa penulis menggunakan rumus skor sama dengan jawaban benar di bagi jumlah pertanyaan dikali 100 (Depdikbud dalam Amellia, 2010:27)

$$
\mathrm{S}=\frac{B}{n} X 100
$$

Keterangan :

S : Skor

B : Jawaban yang benar

n : Jumlah pertanyaan

Tabel 1. Kriteria Ketuntasan Belajar Siswa dalam \%

\begin{tabular}{ccl}
\hline No & Tingkat Keberhasilan (\%) & \multicolumn{1}{c}{ Arti } \\
\hline 1 & $>80 \%$ & Sangat tinggi \\
2 & $60-79 \%$ & Tinggi \\
3 & $40-59 \%$ & Sedang \\
4 & $20-39 \%$ & Rendah \\
5 & $<20 \%$ & Sangat rendah \\
\hline Sumber: Aqib (2011:41) &
\end{tabular}




\section{HASIL DAN PEMBAHASAN}

\subsection{Hasil Observasi}

Pada hasil observasi prasiklus, pengamatan proses pembelajaran terdiri dari minat, kesungguhan, keseriusan, keaktifan, kehangatan suasana, ketertiban, keriuhan suara, dan kelancaran langkah pembelajaran diperoleh hasil berikut. Minat belajar siswa sebesar 65 (cukup), kesungguhan siswa sebesar 64,6 (cukup), keseriusan siswa sebesar 65.3 (cukup), keaktifan siswa sebesar 58.3 (kurang), kehangatan suasana sebesar 66,3 (cukup), ketertiban siswa sebesar 58 (cukup) keriuhan suara siswa sebesar 65,6 (cukup) dan kelancaran langkah pembelajaran sebesar 63,8 (cukup). Dengan menjumlahkan nilai seluruh kriteria dan membaginya, maka diperoleh nilai 63, 3 (cukup) untuk hasil observasi prasiklus. Hasil observasi prasiklus menunjukkan bahwa aktivitas siswa sudah cukup, tetapi perlu dilakukan kembali observasi terhadap aktivitas siswa sebagai upaya untuk perbaikan pada siklus I sehingga aktivitas siswa dapat meningkat menjadi baik.

Selanjutnya, hasil observasi siklus I, pengamatan proses pembelajaran pada minat belajar sebesar 72 (baik), kesungguhan siswa sebesar 70,3 (baik), keseriusan siswa sebesar 69.1 (cukup), keaktifan siswa sebesar 68,8 (cukup), kehangatan suasana sebesar 69,8 (cukup), ketertiban siswa sebesar 72,8 (baik), keriuhan suara siswa sebesar 70,3 (baik) dan kelancaran langkah pembelajaran sebesar 76.6 (baik). Rata-rata dari data hasil observasi Siklus I sebesar 71,4 (baik). Berdasarkan hasil observasi siklus I, diketahui bahwa aktivitas siswa mengalami peningkatan dari prasiklus sebesar $\mathbf{6 3 , 3}$ menjadi 71,4 pada siklus I. Tetapi, perlu dilakukan kembali observasi terhadap aktivitas siswa dapat meningkat menjadi baik.

Hasil observasi siklus II, pengamatan proses pembelajaran diperoleh minat belajar sebesar 82.3 (baik), kesungguhan siswa sebesar 82,3 (baik), keseriusan siswa sebesar 80,1 (baik), keaktifan siswa sebesar 82,1 (baik), kehangatan suasana sebesar 82,6 (baik), ketertiban siswa sebesar 82,3 (baik), keriuhan suara siswa sebesar 81,5 (baik), dan kelancaran langkah pembelajaran sebesar 84,1 (baik). Jadi, rata-rata hasil observasi pada siklus II adalah 82,1 (Baik).

Berdasarkan hasil data observasi prasiklus, Siklus I dan Siklus II, peneliti menyimpulkan bahwa selama proses belajar mengajar berlangsung terjadi peningkatan terhadap aktifitas siswa. Dari kegiatan yang dilakukan oleh siswa, siswa begitu aktif dan tepat dalam menjawab soal diberikan oleh peneliti selama mengikuti proses belajar mengajar. Hal ini dapat dibuktikan dengan peningkatan hasil observasi dari prasiklus. 
Berdasarkan hasil data observasi, peneliti juga menyimpulkan bahwa selama proses belajar mengajar berlangsung terjadi peningkatan terhadap aktifitas siswa. Dari kegiatan yang dilakukan oleh siswa, siswa begitu aktif dan tepat dalam menjawab soal yang diberikan oleh peneliti selama mengikuti proses belajar mengajar. Hal ini dapat dibuktikan dengan peningkatan hasil observasi dari prasiklus 63,3 (cukup) menjadi 71,4 (baik) pada siklus I dan 82,1 (baik) pada siklus II. Dengan demikian, hasil observasi siswa kelas XI IPS 2 SMA Muhammadiyah 2 Palembang selama proses belajar mengajar berlangsung baik.

\subsection{Hasil Tes}

Berikut ini merupakan hasil tes prasiklus yang diberikan kepada 30 siswa.

Tabel 2. Hasil Tes Prasiklus

\begin{tabular}{cccc}
\hline No & Rentang Nilai & Siswa & Persentase (\%) \\
\hline 1 & $40-45$ & 1 & $3,3 \%$ \\
2 & $55-64$ & 13 & $43,3 \%$ \\
3 & $65-77$ & 13 & $43,3 \%$ \\
4 & $75-84$ & 3 & $10 \%$ \\
\hline & Jumlah Siswa & 30 & \\
\hline
\end{tabular}

Dari hasil tes prasiklus yang diberikan, peneliti menunjukan bahwa kemampuan membaca pemahaman wacana narasi siswa kelas XI IPS 2 SMAMuhammadiyah 2 Palembang masih rendah dan diketahui bahwa hanya beberapa siswa yang memenuhi KKM (Kriteria Ketuntasan Minimal) yang ditetapkan sekolah, yaitu 75. Setelah menyelesaikan pembelajaran pada Siklus I, siswa diberikan tes Siklus I. Adapun hasil tes dari Siklus I adalah sebagai berikut.

Tabel 3. Hasil Tes Prasiklus

\begin{tabular}{cccc}
\hline No & Rentang Nilai & Siswa & Persentase (\%) \\
\hline 1 & $55-64$ & 1 & $3,3 \%$ \\
2 & $65-74$ & 14 & $47,7 \%$ \\
3 & $75-84$ & 13 & $43,3 \%$ \\
4 & $85-100$ & 2 & $6,7 \%$ \\
\hline \multicolumn{7}{r}{ Jumlah Siswa } & 30 & \\
\hline
\end{tabular}

Dari hasil tes siklus I yang diperoleh peneliti menunjukan bahwa kemampuan membaca pemahaman wacana narasi siswa kelas XI IPS 2 SMA Muhammadiyah 2 Palembang mengalami peningkatan nilai rata-rata kelas dari 63,83 menjadi 73,77 dengan persentase siswa yang tuntas pada siklus I sebesar $46,6 \%$, dan perlu dilakukan siklus II 
untuk meningkatkan persentase minimal 70\%. Pada hasil tes Siklus II, diperoleh peningkatan kemampuan membaca pemahaman wacana oleh siswa, yaitu sebagai berikut.

Tabel 4. Hasil Tes Prasiklus

\begin{tabular}{cccc}
\hline No & Rentang Nilai & Siswa & Persentase (\%) \\
\hline 1 & $55-64$ & 1 & $3,3 \%$ \\
2 & $65-74$ & 2 & $6,7 \%$ \\
3 & $75-84$ & 4 & $13,3 \%$ \\
4 & $85-100$ & 23 & $76,7 \%$ \\
\hline \multicolumn{2}{r}{ Jumlah Siswa } & 30 & \\
\hline
\end{tabular}

Dari hasil tes siklus II yang diberikan peneliti menunjukan bahwa kemampuan membaca pemahaman wacana narasi siswa kelas XI IPS 2 SMA Muhammadiyah 2 Palembang mengalami peningkatan nilai rata-rata kelas dari 73,77 menjadi 84,3. Peningkatan keterampilan siswa meembaca pemahaman wacana narasi dengan menggunakan metodehyperscan dimulai dari prasiklus, siklus I, dan siklus II dinyatakan pada tabel 5 berikut.

Tabel 5. Peningkatan Keterampilan Membaca Pemahaman

Wacana Narasi Menggunakan Metode Hyperscan

\begin{tabular}{cllc}
\hline No & Tahap & Rata-rata Kelas & \% Klasikal \\
\hline 1 & Prasiklus & 63,83 & $10 \%$ \\
2 & Siklus I & 73,77 & $46,6 \%$ \\
3 & Siklus II & 84,33 & $90 \%$ \\
\hline
\end{tabular}

Peningkatan keterampilan siswa meembaca pemahaman wacana narasi dengan menggunakan metodehyperscanjuga dapat dilihat pada grafik di bawah ini.

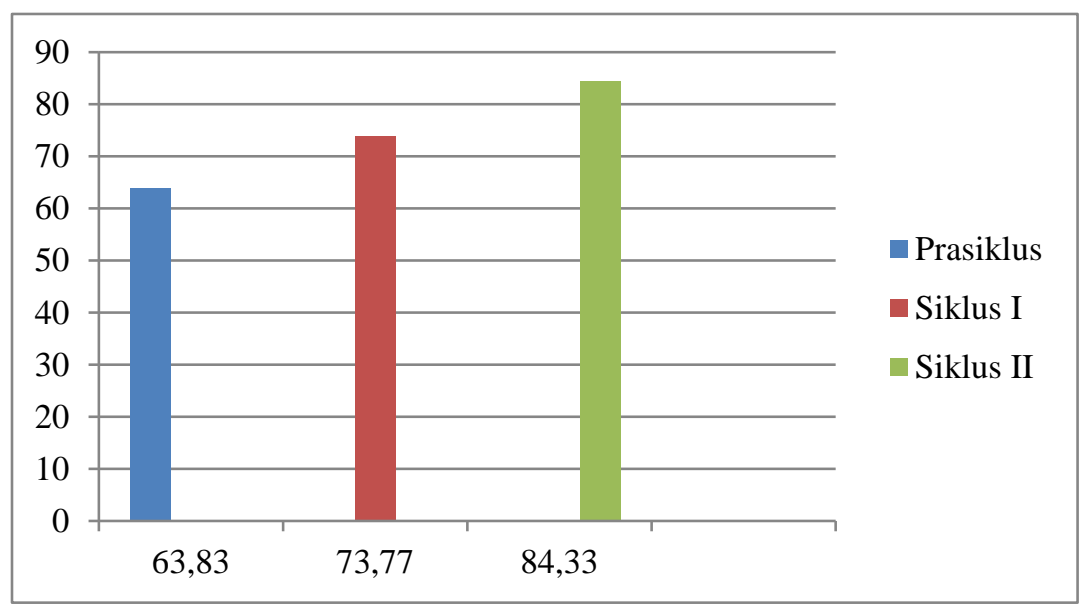

Grafik 1. Peningkatan Keterampilan Siswa Membaca Pemahaman Wacana Narasi Menggunakan Metode Hyperscan 
Dilihat dari grafik dan tabel di atas, peneliti menyimpulkan bahwa penggunaan metode pembelajaran Hyperscan dapat meningkatkan keterampilan membaca pemahaman wacana narasi siswa kelas XI IPS 2 SMA Muhammadiyah 2 Palembang. Hal tersebut dibuktikan dengan adanya peningkatan nilai rata-rata kelas dan jumlah siswa yang memperoleh nilai KKM 75. Peningkatannya dapat dilihat dari tes prasiklus 63,83 menjadi 73,77 pada siklus I, dan 84,33 pada siklus II. Sedangkan dilihat dari persentase keberhasilan secara klasikal ada peningkatan. Tes prasiklus dengan persentase $10 \%$ menjadi $46,6 \%$ pada siklus I, dan $90 \%$ pada siklus II.

Dari hasil penelitian di atas, dapat disimpulkan bahwa penggunaan metode pembelajaran hyperscan dapat meningkatkan keterampilan siswa kelas XI IPS 2 SMAMuhammadiyah 2 Palembang dalam membaca pemahamn wacana narasi. Peningkatan tersebut dapat dilihat dari hasil tes prasiklus, dilanjutkan dengan siklus I dan siklus II. Hasil penelitian ini menunjukkan kesamaan dengan penelitian sebelumnya oleh Oktavia (2018) yang menyatakan bahwa metode hyperscan dapat meningkatkan pembelajaran membaca pemahaman wacana deskripsi. Kriteria Pengujian hipotesis dalam penelitian ini adalah sebagai berikut.

1. Metode pembelajaran Hyperscan dapat meninngkatkan kemampuan membaca pemahaman wacana narasi apabila $78 \%$ siswa sudah mendapat nilai $\geq 75$ berarti tindakan tesebut berhasil.

2. Metode pembelajaran Hyperscan tidak dapat meningkatkan kemampuan membaca pemahaman wacana narasi apabila siswa mendapat nilai $\leq 75$ secara klasikal $78 \%$ berarti tindakan tesebut tidak berhasil.

Dari hasil pengujian hipotesis di atas dapat dinyatakan bahwa siswa kelas XI SMA Muhammadiyah 2 Palembang mengalami peningkatan dalam pembelajaran membaca pemahaman wacana narasi menggunakan metode pembelajaran Hyperscan terbukti kebenarannya.

\section{SIMPULAN}

Dari hasil pembahasan dapat disimpulkan bahwa metode hyperscan dapat meningkatkan pembelajaran membaca pemahaman wacana narasi siswa SMA Muhammadiyah 2 Palembang. Dari hasil penelitian, diperoleh nilai rata-rata siswa siswa 
pada prasiklus adalah 63,83, pada siklus I 73,77 , selanjutnya siklus II 84,33 . Dilihat dari persentase keberhasilan siswa, secara klasikal terjadi peningkatan. Peningkatan tersebut terlihat dari hasil tes prasiklus dengan persentase ketuntasan $10 \%$ menjadi $46,6 \%$ pada siklus I, menjadi 90\% pada siklus II. Dengan demikian, disimpulkan bahwa metode hyperscan dapat meningkatkan keterampilan membaca pemahaman wacana narasi siswa ., Dari hasil pengujian hipotesis di atas dapat dinyatakan bahwa siswa kelas XI SMA Muhammadiyah 2 Palembang mengalami peningkatan dalam pembelajaran membaca pemahaman wacana narasi menggunakan metode pembelajaran Hyperscan terbukti kebenarannya. 
ISSN 1979-8598 E-ISSN: 2655-8378

http://journal.binadarma.ac.id/index.php/jurnalbinaedukasi

Vol. 14, No. 1, Juni 2021, 46 - 58

\section{DAFTAR PUSTAKA}

Arikunto, Suharsimi dkk. 2011. Prosedur Penelitian Suatu Pendekatan Praktek. Jakarta: Rineka Cipta.

Aqib, Zainal. 2011. Penelitian Tidakan Kelas. Bandung: CV Yarma Widia.

Chear, Abdul. 2007. Linguistik Umum. Jakarta: Rineka Cipta.

Depdikbutd. 2016. Kamus Besar Bahasa Indonesia. Jakarta: Balai Pustaka.

Deporter, Bobbi. 2009. Quantum Reader. Bandung: PT. Mizan Pustaka.

Nurhadi. 2011. Membaca Cepat dan aktif. Jakarta: Sinar Baru Algensindo.

Olivia, Femi. 2008. Teknik Membaca Efektif Menciptakan Kebiasaan Belajar yang Efektif dengan Membaca Kritis dan Formula 5S.

Roy Hanny, Nilfa. 2013. "Keefektifan Metode Hyperscan dalam Meningkatkan Membaca Pemahaman Wacana Argumentasi Siswa Kelas VII SMP Negeri 26 Palembang". Skripsi. Palembang: FKIP Universitas Muhammdiyah Palembang.

Sunnendar dan Iskandarwassid 2009. Kemampuan Membaca Efektif dan Efisien. Bandung: Angkasa.

Sudijono, Anas. 2012. Pengantar Statistik Pendidikan. Jakarta: Raja Grafindo Persada.

Sugiyono. 2018. Metode Penelitian Pendidikan Pendekatan Kuantitatif, Kualtitatif, dan $R \& D$. Bandung: Alfabeta.

Suherli, Maman Suryaman, dkk. 2017. Buku Guru Bahasa Indonesia SMA/MA/SMK Kelas XI. Jakarta: Kementerian Pendidikan dan Kebudayaan Republik Indonesia 2017.

Sukardi. 2016. Metode Penelitian Pendidikan Kompetensi dan Praktiknya. Jakarta: Bumi Aksara.

Tarigan, Henry Guntur. 2008. Membaca Sebagai Suatu Keterampilan Berbahasa. Bandung: Percetakan Angkasa.

Tampubolon. 2008. Kemampuan Membaca Teknik Membaca Efektif dan Efisien. Bandung: Percetakan Angkasa.

Yuni, Oktavianni. 2018. "Penggunaan Metode Hyperscan pada Pembelajaran Wacana Deskripsi dapat Meningkatkan Keterampilan Membaca Pemahaman Siswa Kelas XI SMA MUHAMMADIYAH 1 Palembang”. Skripsi. Palembang: FKIP Universitas Muhammdiyah Palembang. 